\title{
Potential predictors of surgical evacuation following early medical abortion: a prospective study
}

\author{
Ritu Bansal*, Naimaa K. Chaudhary, Asha Sharma
}

Department of Obstetrics and Gynaecology, St. Stephen's Hospital, Delhi, India

Received: 22 May 2021

Accepted: 18 June 2021

\author{
*Correspondence: \\ Dr. Ritu Bansal, \\ E-mail: ritubansal2710@gmail.com
}

Copyright: (c) the author(s), publisher and licensee Medip Academy. This is an open-access article distributed under the terms of the Creative Commons Attribution Non-Commercial License, which permits unrestricted non-commercial use, distribution, and reproduction in any medium, provided the original work is properly cited.

\begin{abstract}
Background: Medical management is the safer, effective and more convenient method for the management of missed abortion. Owing to the risk and complications, medical management is offered to all the women presenting with missed abortions. Yet after all possible efforts a large number of patients land up into surgical evacuation. This study is conducted for the in-depth analysis of the patient's presenting complaints and their risk factors to establish the correlation of these factors with failed medical abortion. This would help in the establishment of easily identifiable subgroups for whom medical management would be a success.

Methods: This is a prospective observational study conducted at St. Stephen's hospital Delhi during September 2019June 2020. 55 women with missed abortion attending the gynaecological clinic and emergency, were recruited based on inclusion and exclusion criteria. After taking informed and written consent, all cases were administered misoprostol by vaginal route for medical management. Patients were followed up for 24 hours and looked for the outcome.

Results: We found that multiparity, advanced gestational age and previous caesarean deliveries were the predictors of uterine evacuation following failed medical management. Higher chances of complete abortion were seen among multiparous and among the patients who had bleeding at the time of presentation. Failure of medical management was seen in around $70 \%$ cases with more than 9 weeks gestational age. Lesser side effects are observed with 400 mcg misoprostol dosing.

Conclusions: Nulliparous patients and the patients presenting with bleeding at the time of presentation had more complete abortion. Multiparity and previous caesarean delivery is associated with failed medical management. After studying the potential risk factors, every patient can be counselled about the chances of completion of medical management.
\end{abstract}

Keywords: Missed abortion, Surgical evacuation, Misoprostol

\section{INTRODUCTION}

Missed abortion is defined as a non-viable, intrauterine pregnancy with either an empty gestational sac or a gestational sac containing embryo or fetus without fetal cardiac activity within first $126 / 7$ weeks of gestation. ${ }^{1}$ Early pregnancy loss is common, occurring in $10 \%$ of all cases of clinically recognized pregnancies. ${ }^{2-4}$ Approximately $80 \%$ of all cases of pregnancy loss occur within the first trimester. ${ }^{2,3}$
Missed abortion or early pregnancy failure was traditionally treated with surgical evacuation. However, due to the associated risk of bleeding, perforation, infection, intrauterine adhesion leading to secondary infertility and the women's fear of being subjected to a surgical intervention makes surgical evacuation a second choice in the management of missed abortion. Expectant management is a considerable option but usually refused by some patients in fear of infection and psychological upset. 
Medical management is safer, effective and more convenient. Compared with expectant and surgical management, it shortens the time of complete expulsion without increasing the risk associated with surgical evacuation. Therefore, medical management of missed abortion can be easily considered in women without any other medical or surgical co-morbidity. The largest U.S. trial reported that success rates after medical management of an-embryonic gestation $(81 \%)$ was lower than with embryonic or fetal death $(88 \%)$ or incomplete or inevitable pregnancy loss $(93 \%) .^{5}$

Owing to the risk and complications, in our institute we offer medical management to all the women presenting with missed abortions. Yet after all possible efforts a large number of patients land up into surgical evacuation. This study is conducted for the in-depth analysis of the patient's presenting complaints and their risk factors to establish the correlation of these factors with failed medical abortion. This would help in the establishment of easily identifiable subgroups for whom medical management would be a success and some women for whom surgical management would be a success.

Several studies have evaluated the efficacy of medical treatment for early pregnancy failure. Previous attempts have been made to recognize potential risk factors responsible for failed medical management of missed abortions. Multiparity, previous abortions, previous caesarean deliveries are proven to be the risk factors for failed medical management. ${ }^{6}$ On the other hand, presence of pain or bleeding in the last 24 hours of presentation could be contributing factors in the complete abortion with medical management. ${ }^{7}$ In the present study we sought to confirm the above findings.

\section{METHODS}

This is a prospective observational study. Study duration was from September 2019-June 2020. Fifty-five pregnant women, who were diagnosed with missed abortion attending the gynaecological clinic and emergency, were recruited based on inclusion and exclusion criteria.

\section{Inclusion criteria}

The patients who had Primi/multi gravida with singleton pregnancy with ultrasound depicted intrauterine gestational sac of size 12 weeks or less with missed abortion and patients presenting with incomplete abortion (hemodynamically stable) were included in the study.

\section{Exclusion criteria}

Grand-multipara, women allergic to misoprostol, patients with hemoglobin below $8 \mathrm{gm}$, cardio vascular disease, hemorrhagic disease, pregnancy with IUCD in situ, women with uterine anomaly, patients with extrauterine pregnancy were excluded from the study.

\section{Procedure}

All eligible patients were explained about the procedure, advantages and disadvantages of both medical and surgical abortion and informed consent was obtained for medical management. Detailed clinical history including the history of presenting complaints was taken, past medical and surgical history was taken. Past menstrual history along with thorough obstetric history (previous mode of delivery and regarding abortions (if any) the mode of termination of pregnancy) was obtained. All baseline investigations including complete blood count, blood grouping, urine examination, serology, and thyroid function test was carried out. Any abnormality in laboratory investigation observed and noted accordingly.

Patients were given $400 \mathrm{mcg}$ of misoprostol vaginally and repeated 4 hrly (max 3 doses) and examined at $4 \mathrm{~h}$ interval.

Patients were advised to inform when they would pass the product of conception and the products were sent for histopathological examination. Emergency surgical evacuation was performed in case of heavy bleeding. Follow up ultrasound pelvis was performed to confirm complete expulsion of products after 12 hours of last dose. Surgical evacuation was performed when a persistent gestational sac was still present or if there was a significant amount of the products of conception in the uterus with or without clinical evidence of heavy vaginal bleeding. If the ultrasound examination had shown evidence of complete abortion or incomplete abortion but without heavy vaginal bleeding, no action was taken. The amount of bleeding was monitored and the woman was asked to come back after a week for follow up. The collected data was transformed into variables, coded and entered in Microsoft excel. Data was analyzed and statistically evaluated using SPSS-PC21 version. Quantitative data was expressed in mean \pm standard deviation and depends on normality distribution, difference between two comparable groups were tested by student's t-test (unpaired) while qualitative data were expressed in percentage and statistical differences between the proportions were tested by chi square test or Fisher's exact test. ' $P$ ' value less than 0.05 was considered statistically significant.

\section{RESULTS}

In the present study a total of 55 patients with the diagnosis of missed abortion were given medical management. Among these $45.5 \%$ patients had complete abortion and $54.5 \%$ had incomplete abortions, which were subsequently managed with suction aspiration.

Table 1: Effect of medical management in study subjects, $(\mathbf{n}=55)$.

\begin{tabular}{|lll|}
\hline $\begin{array}{l}\text { Effect of medical } \\
\text { management }\end{array}$ & No. & $\begin{array}{l}\text { Percentage } \\
(\%)\end{array}$ \\
\hline Incomplete abortion & 30 & 54.5 \\
\hline Complete abortion & 25 & 45.5 \\
\hline Total & 55 & 100.0 \\
\hline
\end{tabular}


Table 2: Age-wise distribution of study subjects.

\begin{tabular}{|c|c|c|c|c|c|c|}
\hline \multirow{2}{*}{$\begin{array}{l}\text { Age } \\
\text { group } \\
\text { (Years) }\end{array}$} & \multicolumn{2}{|c|}{$\begin{array}{l}\text { Incomplete } \\
\text { abortion, } \\
(\mathbf{n}=\mathbf{3 0})\end{array}$} & \multicolumn{2}{|c|}{$\begin{array}{l}\text { Complete } \\
\text { abortion, } \\
(\mathbf{n}=\mathbf{2 5})\end{array}$} & \multicolumn{2}{|c|}{$\begin{array}{l}\text { Total, } \\
(n=55)\end{array}$} \\
\hline & No. & $\%$ & No. & $\%$ & No. & $\%$ \\
\hline $\begin{array}{l}\text { Less } \\
\text { than } 20\end{array}$ & 0 & 0.0 & 2 & 8.0 & 2 & 3.6 \\
\hline 21-25 & 7 & 23.3 & 5 & 20.0 & 12 & 21.8 \\
\hline $26-30$ & 12 & 40.0 & 13 & 52.0 & 25 & 45.4 \\
\hline 31-35 & 9 & 30.0 & 4 & 16.0 & 13 & 23.6 \\
\hline$>35$ & 2 & 6.7 & 1 & 4.0 & 3 & 5.4 \\
\hline
\end{tabular}

$\mathrm{P}=0.23$

The study was carried out in females of age between 1838 years. Maximum patients were in the age group of $26-$ 30 years (forty percentage in incomplete abortion group and $52 \%$ in complete abortion group). The distribution of mean age among incomplete and complete abortion patients is $29.43 \pm 4.30$ and $27.40 \pm 3.91$ years respectively ( $p$ value of $=0.19$ ). The association of the age group distribution with uterine evacuation is not statistically significant.

Table 3: Association of current gestational age with complete abortion following medical management.

\begin{tabular}{|c|c|c|c|c|c|}
\hline \multirow{2}{*}{$\begin{array}{l}\text { Current } \\
\text { gestational } \\
\text { age } \\
\text { (weeks) }\end{array}$} & \multicolumn{2}{|c|}{$\begin{array}{l}\text { Incomplete } \\
\text { abortion, } \\
(\mathbf{n = 3 0})\end{array}$} & \multicolumn{2}{|c|}{$\begin{array}{l}\text { Complete } \\
\text { abortion, } \\
(\mathbf{n}=\mathbf{2 5})\end{array}$} & \multirow{2}{*}{$\begin{array}{l}\text { Chi } \\
\text { square } \\
\text { value; } \\
\text { p value }\end{array}$} \\
\hline & No. & $\%$ & No. & $\%$ & \\
\hline Up to 9 & 9 & 30.0 & 16 & 64.0 & \multirow{2}{*}{$\begin{array}{l}\chi^{2}=6.35 \\
p=0.01\end{array}$} \\
\hline$>9$ & 21 & 70.0 & 9 & 36.0 & \\
\hline
\end{tabular}

As per the present study more cases of complete abortion were observed among the patients with gestational age up to 9 weeks $(\mathrm{p}=0.01)$ Higher gestational age (more than 9 weeks) was associated with more cases of incomplete abortion and so more of uterine evacuation $(70 \%)$. The distribution of mean gestational age among incomplete and complete abortion patients is $10.0 \pm 1.57$ and $8.76 \pm 1.76$ weeks respectively.

Table 4: Association of parity with complete abortion following medical management.

\begin{tabular}{|c|c|c|c|c|c|}
\hline \multirow{2}{*}{$\begin{array}{l}\text { Parity } \\
\text { status of } \\
\text { mother }\end{array}$} & \multicolumn{2}{|c|}{$\begin{array}{l}\text { Incomplete } \\
\text { abortion, } \\
(\mathbf{n}=\mathbf{3 0})\end{array}$} & \multicolumn{2}{|c|}{$\begin{array}{l}\text { Complete } \\
\text { abortion, } \\
(\mathbf{n}=25)\end{array}$} & \multirow[t]{2}{*}{$\mathbf{P}$ value } \\
\hline & No. & $\%$ & No. & $\%$ & \\
\hline Nullipara & 11 & 36.7 & 19 & 76.0 & \multirow{2}{*}{$\begin{array}{l}\chi^{2}=8.51 ; \\
p=0.006 \\
<0.01\end{array}$} \\
\hline Multipara & 19 & 63.3 & 6 & 24.0 & \\
\hline
\end{tabular}

Out of all the patients who had complete abortion nineteen $(76 \%)$ patients were nulliparous and $6(24 \%)$ patients were multiparous. There was a significant association with nulliparity and complete abortion ( $p$ value of $<0.01$ ).
Table 5: Association of previous abortion with complete abortion following medical management.

\begin{tabular}{|c|c|c|c|c|c|}
\hline \multirow[t]{2}{*}{$\begin{array}{l}\text { Previous } \\
\text { abortion }\end{array}$} & \multicolumn{2}{|c|}{$\begin{array}{l}\text { Incomplete } \\
\text { abortion, } \\
(\mathbf{n = 3 0})\end{array}$} & \multicolumn{2}{|c|}{$\begin{array}{l}\text { Complete } \\
\text { abortion, } \\
(\mathbf{n}=25)\end{array}$} & \multirow{2}{*}{$\begin{array}{l}\text { Chi } \\
\text { square } \\
\text { value; } \\
\text { p value }\end{array}$} \\
\hline & No. & $\%$ & No. & $\%$ & \\
\hline Yes & 10 & 33.3 & 6 & 24.0 & \multirow{2}{*}{$\begin{array}{l}\chi^{2}=0.57 \\
p=0.55\end{array}$} \\
\hline No & 20 & 66.7 & 19 & 76.0 & \\
\hline
\end{tabular}

Table 6: Association of method of management of previous abortion with complete abortion following medical management in present pregnancy.

\begin{tabular}{|c|c|c|c|c|c|}
\hline \multirow{2}{*}{$\begin{array}{l}\text { Management } \\
\text { of previous } \\
\text { abortion }\end{array}$} & \multicolumn{2}{|c|}{$\begin{array}{l}\text { Incomplete } \\
\text { abortion, } \\
(\mathbf{n}=10)\end{array}$} & \multicolumn{2}{|c|}{$\begin{array}{l}\text { Complete } \\
\text { abortion, } \\
(\mathbf{n}=\mathbf{6})\end{array}$} & \multirow{2}{*}{$\begin{array}{l}\text { Chi } \\
\text { square } \\
\text { value; } p \\
\text { value }\end{array}$} \\
\hline & No. & $\%$ & No. & $\%$ & \\
\hline $\begin{array}{l}\text { Medical } \\
\text { management }\end{array}$ & 8 & 80.0 & 2 & 33.3 & \multirow{2}{*}{$\begin{array}{l}\chi^{2} ; \\
p=0.11\end{array}$} \\
\hline $\begin{array}{l}\text { Surgical } \\
\text { management }\end{array}$ & 2 & 20.0 & 4 & 66.7 & \\
\hline
\end{tabular}

Table 7: Association of number of vaginal deliveries with complete abortion following medical management.

\begin{tabular}{|c|c|c|c|c|c|}
\hline \multirow{2}{*}{$\begin{array}{l}\text { No. of } \\
\text { previous } \\
\text { vaginal } \\
\text { deliveries }\end{array}$} & \multicolumn{2}{|c|}{$\begin{array}{l}\text { Incomplete } \\
\text { abortion, } \\
(\mathrm{n}=\mathbf{3 0})\end{array}$} & \multicolumn{2}{|c|}{$\begin{array}{l}\text { Complete } \\
\text { abortion, } \\
(\mathbf{n}=\mathbf{2 5})\end{array}$} & \multirow{2}{*}{$\begin{array}{l}\text { Chi } \\
\text { square } \\
\text { value; } \\
\text { p value }\end{array}$} \\
\hline & No. & $\%$ & No. & $\%$ & \\
\hline $\mathbf{0}$ & 23 & 76.7 & 19 & 76.0 & \multirow{3}{*}{$\begin{array}{l}\chi^{2}=1.89 \\
p=0.38\end{array}$} \\
\hline 1 & 5 & 16.7 & 2 & 8.0 & \\
\hline$\geq 2$ & 2 & 6.7 & 4 & 16.0 & \\
\hline
\end{tabular}

In the present study among patients who had complete abortion following medical management $(n=25)$, only 2 $(8 \%)$ patients had previous one vaginal delivery and 4 (16\%) patients had more than one vaginal delivery. Among the patients with incomplete abortion $(n=30), 5$ $(16.7 \%)$ patients had previous one vaginal delivery and 2 $(6.7 \%)$ patients had more than one vaginal delivery. Thus, number of previous vaginal delivery was not statistically significant.

Table 8: Association of number of prior caesarean section with complete abortion following medical management.

\begin{tabular}{|c|c|c|c|c|c|}
\hline \multirow{2}{*}{$\begin{array}{l}\text { No. of } \\
\text { prior } \\
\text { caesarean } \\
\text { section }\end{array}$} & \multicolumn{2}{|c|}{$\begin{array}{l}\text { Incomplete } \\
\text { abortion, } \\
(\mathbf{n = 3 0})\end{array}$} & \multicolumn{2}{|c|}{$\begin{array}{l}\text { Complete } \\
\text { abortion, } \\
(\mathbf{n = 2 5})\end{array}$} & \multirow{2}{*}{$\begin{array}{l}\text { Chi } \\
\text { square } \\
\text { value; p } \\
\text { value }\end{array}$} \\
\hline & No. & $\%$ & No. & $\%$ & \\
\hline $\mathbf{0}$ & 18 & 60.0 & 25 & 100.0 & \multirow{2}{*}{$\begin{array}{l}\chi^{2}=12.79 ; \\
p=0.0002, \\
<0.001\end{array}$} \\
\hline$\geq 1$ & 12 & 40.0 & 0 & 0.0 & \\
\hline
\end{tabular}

Of all the patients who had complete abortion following medical management none had a history of previous 
caesarean, while among patients who had incomplete abortion $12(40 \%)$ patients had history of previous caesarean. There is a clear association of previous caesarean delivery with incomplete abortion in the present pregnancy which is statistically significant ( $p$ value of $<0.001)$.

Table 9: Association of pain and bleeding with complete abortion following medical management.

\begin{tabular}{|llllll|} 
Variables & $\begin{array}{l}\text { Incomplete } \\
\text { abortion, } \\
(\mathbf{n = 3 0 )}\end{array}$ & $\begin{array}{l}\text { Complete } \\
\text { abortion, } \\
\text { No. }\end{array}$ & $\%$ & $\begin{array}{l}\text { Chi } \\
\text { Non })\end{array}$ & $\begin{array}{l}\text { Nquare } \\
\text { value; } \\
\text { p value }\end{array}$ \\
\hline Pain & & & & & \\
\hline Yes & 18 & 60.0 & 12 & 48.0 & $\chi^{2}=0.79 ;$ \\
No & 12 & 40.0 & 13 & 52.0 & $\mathrm{p}=0.42$ \\
\hline Bleeding & & & & & \\
\hline Yes & 12 & 40.0 & 18 & 72.0 & $\chi^{2}=5.63 ;$ \\
No & 18 & 60.0 & 7 & 28.0 & $\mathrm{p}=0.02$ \\
\hline
\end{tabular}

Among the patients with incomplete abortion $12(40 \%)$ patients and among those with complete abortion $18(72 \%)$ patients had bleeding per vaginum as the presenting complaint. The association of bleeding per vaginum at the time of admission was significantly associated with complete abortion $(\mathrm{p}=0.02)$.

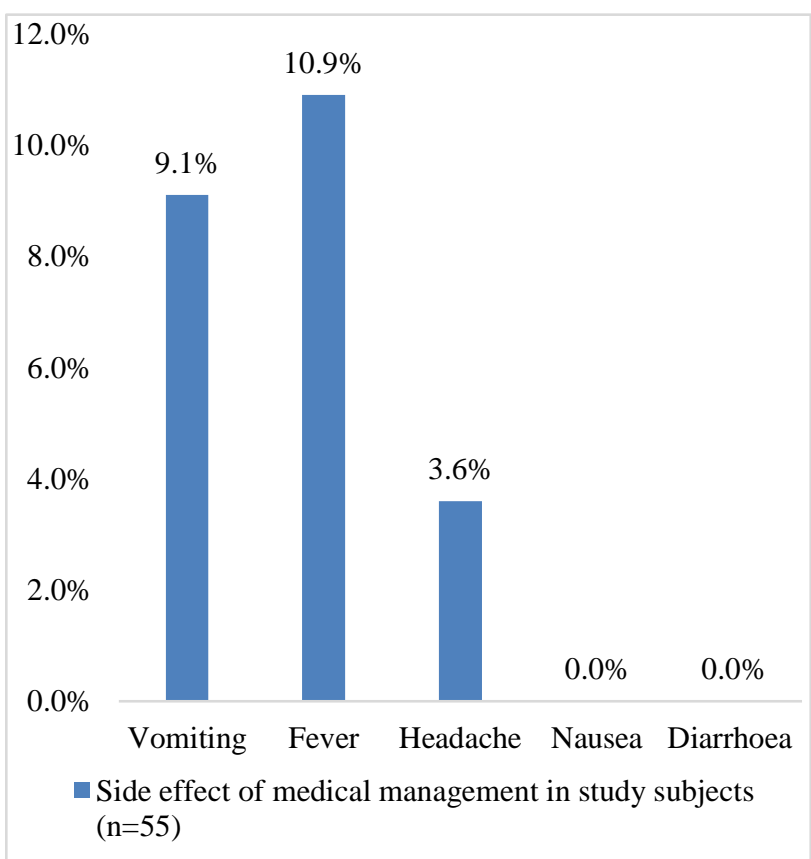

Figure 1: Side effect of medical management in study subjects, $(\mathrm{n}=\mathbf{5 5})$.

In the study $6(10.9 \%)$ patients had fever after misoprostol administration. $5(9.1 \%)$ patients had vomiting and only 2 (3.6\%) patients had headache which was relieved by analgesics. None of our patients had nausea or diarrhoea. Very few side effects were observed with the used misoprostol regimen in the present study.

\section{DISCUSSION}

The effect of age, gestational age, previous pregnancy and previous termination on complete abortion rates following the medical regimen was studied.

Among all the patients, medical management was successful in $45.5 \%$ patients who had complete abortion. $54.5 \%$ of the total patients had incomplete abortion and were managed subsequently with suction evacuation.

We found that multiparity, advanced gestational age ( $>9$ weeks) and previous caesarean deliveries were the predictors of uterine evacuation following failed medical management. Higher chances of complete abortion were seen among the patients who had bleeding at the time of presentation. Nulliparous patients and patients with gestational age less than 9 weeks had higher rate of complete abortion.

However, no such association was seen with the age of the patient, pre-pregnancy BMI, previous abortions or their methods of management (medical or surgical), previous number of vaginal deliveries, Rh blood type and previous medical history.

Maximum number of patients in the study population belongs to the age group of 26-30 years. No significant association of the age distribution was traced with regard to failure of medical management in the study population.

However, in the study performed by Kochman et al older age was associated with unsuccessful medical abortion. ${ }^{21}$ In contrast to this study, Reeves et al. pooled data from multicenter medical abortion trial and found that women aged 20 years or younger were more predictive of uterine evacuation. ${ }^{6}$

In the year 2016 Allam et al performed an observational analytical study in Egypt. In this study, failed cases significantly had higher maternal age and parity. ${ }^{23}$

Meaidi et al in 2019 gave a detailed assessment of the association between maternal age and risk of surgical intervention also in very young women and for women aged 40-49 years, thereby revealing a u-shaped curve. Both these age groups are associated with failed medical management. ${ }^{27}$

In the present study the mean pre-pregnancy BMI of patients is similar in patients who had complete and incomplete abortion. The mean pre pregnancy BMI among incomplete and complete abortion patients is $25.59 \pm 2.29$ and $25.99 \pm 3.60$ respectively $(\mathrm{p}=0.68)$. No significant association of BMI with complete abortion was established in the present study.

This finding is supported by the study of Reeves et al who pooled data from more than 2000 patients to determine the 
predictors of uterine evacuation. In their study body mass index was not predictive of uterine evacuation.

In the present study significant association was found between complete abortion and nulliparity. Out of the all the patients who had complete abortion $76 \%$ patients were nulliparous and $24 \%$ patients were multiparous. There was a significant association with nulliparity and complete abortion. However, no relation was established between advancing parity and incomplete abortion in the present study $(\mathrm{p}=0.38)$ which was previously established by Reeves et al. who demonstrated grand multiparity as the predictor of failed medical management $(\mathrm{OR}=3.2){ }^{6}$ Similar result was seen in the study of Kochman et al in which multigravidity was associated with unsuccessful abortion $(\mathrm{OR}=5.5) .^{21}$

Parity has already been cited as a prognostic factor for incomplete abortion and ongoing pregnancy in an attempt to terminate pregnancy. ${ }^{17,26,27}$

In a retrospective study of 3,161 consecutive cases of treated early medical abortion, Bartley and his colleagues reported that parity is a major determinant of successful medical abortion; with parous women being twofold more likely to have incomplete abortion or ongoing pregnancy. ${ }^{28}$

Likewise, Ashok et al studied 4,132 women undergoing early medical abortion (with mifepristone followed by misoprostol one or 2 doses) found that women with a previous live birth but without a prior termination were more likely to have a failed medical abortion (odds ratio 2.03). ${ }^{18}$

Creinin also demonstrated that successful medical treatment of early pregnancy failure with misoprostol is significantly more likely in women who are nulliparous $(\mathrm{p}=0.05){ }^{7}$ Aldrich et al also showed that parous women were less likely to have successful abortions than their nulliparous counterparts. ${ }^{30}$

Prefumo et al demonstrated that trophoblastic invasion of the decidual vessels in early pregnancy is significantly more extensive in parous than in nulliparous women. This imply that there is greater trophoblastic adherence during tissue expulsion among parous women. This explains their increased odds of failed medical abortion as compared to nulliparous women. The probability of failed medical abortion was similar in women with one vaginal delivery compared with those with multiple vaginal deliveries, which was also seen in the present study. Similarly, women with prior caesarean delivery, regardless of the number, had a comparable likelihood of failed medical abortion. No significant increase in the odds of failed abortion was seen as the number of previous live births increased. ${ }^{25}$

Creinin has suggested that stretching of the myometrium with past pregnancies may alter the receptivity of the uterus to misoprostol, subsequently decreasing the probability of successful medical abortion in parous women. $^{7}$

Chien et al, in their study, also concluded that parous women are at increased risk for failed medical abortion in comparison with nulliparous women. Prior caesarean delivery is significantly associated with failed medical abortion. Chien et al found that the probability of failed medical abortion was increased more than three times (OR 3.94) from nulliparity to the first birth. In addition, compared with nulliparous women, those with prior caesarean delivery were nine times more likely to have a failed abortion. ${ }^{22}$

Reeves et al in the year 2015, pooled data from 2 multicentre medical abortion trials, to determine the predictors of early medical abortions. In multivariable analysis, 5 or more prior deliveries (AR 11.9\%, OR 4.6) were significantly associated with uterine evacuation. ${ }^{6}$

In the year 2016 Allam et al found that failed cases significantly had higher maternal age and parity. ${ }^{23}$

Previous caesarean delivery is significantly associated with failed medical management. In the present study, all patients with previous caesarean did not undergo complete abortion with medical therapy $(\mathrm{p}=0.0002)$.

Chien et al. found that those with prior caesarean delivery were nine times more likely to have a failed abortion. ${ }^{22}$ Among parous women, women with ever caesarean delivery had a threefold increase in the failure rate of medical abortion over those with prior vaginal delivery. It is likely that caesarean deliveries injure uterine muscle, impair integration, and reduce its physiologic stretching in early pregnancy. Also scar formation in the lower uterus may restrict spontaneous expulsion of the gestational tissue from an unripe cervix in the first trimester.

In the present study mean gestational age for patients with incomplete abortion was $10.0 \pm 1.57$ weeks and complete abortion was $8.76 \pm 1.76$ weeks. Gestational age more than 9 weeks was associated with more incomplete abortion $(\mathrm{p}=0.01)$.

Advanced gestational age has already been cited as a prognostic factor for incomplete abortion and ongoing pregnancy in an attempt to terminate pregnancy. ${ }^{17,18,26}$

Reeves et al in the year 2015 in multivariable analysis, 5 or more prior deliveries (AR 11.9\%, OR 4.6) and gestational age of 8 weeks or more (AR 4.1\%, OR 2.1) were significantly associated with uterine evacuation. ${ }^{6}$

In the present study, presenting complaint of pain at the time of admission did not have significance association with complete abortion $(\mathrm{p}=0.37)$. However, bleeding at the time of presentation was significantly associated with complete medical abortion $(\mathrm{p}=0.01)$. 
In 2006, Creinin et al included 485 women who were medically managed for early pregnancy failure in their study. They demonstrated that successful treatment was significantly more in women who were nulliparous or who have localized abdominal pain within the last 24 hours, vaginal bleeding within the last 24 hours and those who had an Rh negative blood type. ${ }^{7}$

It may be hypothesized that $\mathrm{Rh}$ mismatch could be an underlying cause of an early pregnancy failure creating a situation for misoprostol to be effective.

In the present study number of patients with Rh negative pregnancy was too less to draw a significant association.

In 2016, Allam et al conducted a study in which failed cases significantly had higher maternal age and parity. The mean sac diameter was significantly low in successful cases. Patient with lower abdominal pain in the last 24 hours responded well to the medical method, whereas clinical factors like previous caesarean section and vaginal bleeding did not make any statistical difference. Based on the results of the study, authors formulated a scoring system using which the success of a medical abortion can definitely be predicted. ${ }^{23}$

\section{Side effects}

The common side effects observed with misoprostol in the present study were lesser. Vomiting was observed in $9.1 \%$ and headache was observed in $3.6 \%$ patients. Overall, the side effects in the current study were minimal and manageable.

\section{Limitations}

Single centre study with small sample size. Study group comprised of low-risk population. Sample volume is less. More patients are required for evaluation of significance of predictive test. This study was not designed to predict an algorithm for accurately predicting medical management success or failure.

\section{CONCLUSION}

Complete abortion was more common among patients with gestational age of less than 9 weeks. Vaginal misoprostol is safe and effective alternative to surgical evacuation in cases of missed abortion. Data from this study and other clinical studies provide strong and consistent support for the use of misoprostol for termination of first trimester missed abortion.

Nulliparous patients have higher chances of complete abortion. Also, the patients presenting with bleeding at the time of presentation had more complete abortion. Multiparity and previous caesarean delivery is associated with failed medical management.
Complete abortion rate was less in the present study. We conclude that this could be due to suboptimal misoprostol dosing. However, this dosing of misoprostol was associated with lesser side effects. After studying the potential risk factors, every patient can be counselled about the chances of completion of medical management, or the chances of requirement of surgical evacuation if medical management fails. Larger studies are needed to compare these findings. Repeat dosing of misoprostol should be tried before deciding for surgical evacuation. Depending on the studied potential predictors each patient should be counselled regarding the chances of suction evacuation prior to starting the medical management.

Although some women may have slightly higher risk of ultimately leading and requesting a uterine aspiration, all women should be offered medical abortion.

\section{Funding: No funding sources}

Conflict of interest: None declared

Ethical approval: The study was approved by the Institutional Ethics Committee

\section{REFERENCES}

1. National Institute of Health and Care excellence. Ectopic pregnancy and miscarriage: diagnosis and initial management. National Institute of Health and Care excellence guideline. 2019;126:1-32

2. Wilcox AJ, Weinberg CR, O'Connor JF, Baird DD, Schlatterer JP, Canfield RE et al. Incidence of early loss of pregnancy. N Engl J Med. 1988;319(4):18994.

3. Wang X, Chen C, Wang L, Chen D, Guang W, French J. Conception, early pregnancy loss, and time to clinical pregnancy: a population-based prospective study. Fertil Steril. 2003;79(3):577-84.

4. Zinaman MJ, Clegg ED, Brown CC, O’Connor J, Selevan SG. Estimates of human fertility and pregnancy loss. Fertil Steril. 1996;65(3):503-9.

5. Zhang J, Gilles JM, Barnhart K, Creinin MD, Westhoff C, Frederick MM et al. A comparison of medical management with misoprostol and surgical management for early pregnancy failure. N Engl J Med. 2005;353(8):761-9.

6. Reeves MF, Monmaney JA, Creinin MD. Predictors of uterine evacuation following early medical abortion with mifepristone and misoprostol. Contraception. 2016;93(2):119-25.

7. Creinin MD, Huang $\mathrm{X}$, Westhoff $\mathrm{C}$, Barnhart $\mathrm{K}$, Gilles JM, Zhang $\mathrm{J}$ et al. Factors related to successful misoprostol treatment for early pregnancy failure. Obstet Gynecol. 2006;107(4):901-7.

8. Moore KL. The Developing Human: Clinically Oriented Embryology. Philadelphia, WB Saunders. 1977;2.

9. Stephenson MD, Awartani KA, Robinson WP. Cytogenetic analysis of miscarriages from couples with recurrent miscarriage: a case-control study. Hum Reprod Oxf Engl. 2002;17(2):446-51. 
10. Practice Committee of the American Society for Reproductive Medicine. Evaluation and treatment of recurrent pregnancy loss: a committee opinion. Fertil Steril. 2012;98(5):1103-11.

11. Barnhart KT. Early pregnancy failure: beware of the pitfalls of modern management. Fertil Steril. 2012;98(5):1061-5.

12. Doubilet PM, Benson CB, Bourne T, Blaivas M. Society of Radiologists in Ultrasound Multispecialty Panel on Early First Trimester Diagnosis of Miscarriage and Exclusion of a Viable Intrauterine Pregnancy. Diagnostic criteria for nonviable pregnancy early in the first trimester. Ultrasound Q. 2014;30(1):3-9.

13. Arias F, Bhide AG, Arulkumaran S, Damania K, Daftary SN. Arias' Practical Guide to High-Risk Pregnancy and Delivery: A South Asian Perspective. Elsevier India. 2019;25.

14. Early pregnancy loss. ACOG Practice Bulletin. American College of Obstetricians and Gynecologists. Obstet Gynecol. 2018;132:e197-207.

15. Ahmad B, Shekhar C, Jindal S, Gupta S. Misoprostol for induction of labour: a comparative study of various routes of administration. Int $\mathbf{J}$ Reprod Contracept Obstet Gynecol. 2017;6(10):4583.

16. Zieman M, Fong SK, Benowitz NL, Banskter D, Darney PD. Absorption kinetics of misoprostol with oral or vaginal administration. Obstet Gynecol. 1997;90(1):88-92.

17. Ashok PW, Penney GC, Flett GM, Templeton A. An effective regimen for early medical abortion: a report of 2000 consecutive cases. Hum Reprod Oxf Engl. 1998;13(10):2962-5.

18. Ashok PW, Templeton A, Wagaarachchi PT, Flett GMM. Factors affecting the outcome of early medical abortion: a review of 4132 consecutive cases. Int $\mathbf{J}$ Obstetr Gynaecol. 2002;109(11):1281-9.

19. Spitz IM, Bardin CW, Benton L, Robbins A. Early pregnancy termination with mifepristone and misoprostol in the United States. N Engl J Med. 1998;338(18):1241-7.

20. Behnamfar F, Mahdian M, Rahimi F, Samimi M. Misoprostol Abortion: Ultrasonography versus BetahCG Testing for Verification of Effectiveness. Pak J Med Sci. 2013;29(6):1367-70.

21. Haimov-Kochman R, Arbel R, Sciaky-Tamir Y, Brzezinski A, Laufer N, Yagel S. Risk factors for unsuccessful medical abortion with mifepristone and misoprostol. Acta Obstet Gynecol Scand. 2007;86(4):462-6.

22. Chien L-W, Liu W-M, Tzeng C-R, Au H-K. Effect of previous live birth and prior route of delivery on the outcome of early medical abortion. Obstet Gynecol. 2009;113(3):669-74.

23. Allam NE, Mohamed TM, Wahba SM. Designing a Scoring System for Predicting Effectiveness of Misoprostol-Alone Regimen Used in Early Pregnancy Failure. 2016;3:10.

24. Karmyshev AO, Ryskel'dieva VT, Sorokin AA. Efficiency of various methods for termination of nondeveloping early pregnancy: A randomized clinical trial. Ross Vestn Akushera-Ginekol. 2017;17(2):64.

25. refumo F, Ganapathy R, Thilaganathan B, Sebire NJ. Influence of parity on first trimester endovascular trophoblast invasion. Fertil Steril. 2006;85(4):1032-6.

26. Niinimäki M, Martikainen H, Talvensaari-Mattila A. Increased risk for medical abortion failure for multiparous women. Int J Gynaecol Obstet Off Organ Int Fed Gynaecol Obstet. 2004;87(2):174-5.

27. Meaidi A, Friedrich S, Gerds TA, Lidegaard O. Risk factors for surgical intervention of early medical abortion. Am J Obstet Gynecol. 2019;220(5):478.e115.

28. Bartley J, Tong S, Everington D, Baird DT. Parity is a major determinant of success rate in medical abortion: a retrospective analysis of 3161 consecutive cases of early medical abortion treated with reduced doses of mifepristone and vaginal gemeprost. Contraception. 2000;62(6):297-303.

29. Rorbye C. Prediction of late failure after medical abortion from serial -hCG measurements and ultrasonography. Hum Reprod. 2004;19(1):85-9.

30. Aldrich T, Winikoff B. Does methotrexate confer a significant advantage over misoprostol alone for early medical abortion? A retrospective analysis of 8678 abortions. Int J Obstet Gynaecol. 2007;114(5):555-62.

Cite this article as: Bansal R, Chaudhary NK,

Sharma A. Potential predictors of surgical evacuation following early medical abortion: a prospective study. Int J Reprod Contracept Obstet Gynecol 2021;10:2768-74. 